\title{
PENGEMBANGAN MEDIA GEO-SD (GEOMETRI SKETSA DIMENSI) SEBAGAI PENUNJANG KEMAMPUAN VISUAL SPASIAL
}

\author{
Rachmaniah M. Hariastuti ${ }^{1)}$, Dwi Anita ${ }^{2)}$, Moh. Ade Setiawan ${ }^{3)}$ \\ 1), 2), ${ }^{3)}$ Universitas PGRI Banyuwangi \\ E-mail: $\quad$ mirzarachmania@gmail.com ${ }^{1)}$ \\ da.dwianita@gmail.com ${ }^{2)}$ \\ accesszigmas@gmail.com ${ }^{3)}$
}

\begin{abstract}
Every student generally has multiple intelligences with different level, one of which is visual-spatial intelligence shown by the ability to visualize an object. To acquire this kind of intelligence one can utilize media. This research, aiming at developing such a media, uses ADDIE model which is designed based on printed media which then followed by designing the electronic ones. Subjects of the research are 9 students selected by random technique. The research result electronic quiz media which can be utilized by students in interpreting $3 D$ objects into $2 D$ ones or vice versa.
\end{abstract}

Keywords: electronic quiz media; geometry objects; visual-spatial intelligence.

\section{PENDAHULUAN}

Setiap manusia terlahir dengan berbagai kecerdasan. Intelligence (kecerdasan) merupakan kemampuan beradaptasi dengan lingkungan baru atau perubahan dalam lingkungan, kapasitas pengetahuan dan kemampuan untuk memperolehnya, kapasitas untuk memberikan alasan dan berpikir abstrak, kemampuan untuk memahami hubungan, mengevaluasi dan menilai, serta kapasitas untuk menghasilkan pikiran-pikiran produktif dan original (Yaumi, 2012:11). Kecerdasan yang dimiliki setiap manusia seharusnya dapat membuat manusia tersebut mengembangkan diri dengan memperhatikan kecerdasan yang paling optimal.

Howard Gardner menyediakan sarana untuk memetakan berbagai kecerdasan yang dimiliki manusia, dengan mengelompokkannya menjadi delapan kategori, yaitu: (1) kecerdasan verbal-linguistik, (2) logis-matematis, (3) visual-spasial, (4) berirama-musik, (5) jasmaniah-kinestetik, interpersonal, (7) intrapersonal, dan (8) naturalistik (Yaumi, 2012:12).
Kedelapan jenis kecerdasan tersebut biasa dinamakan dengan Multiple Inteligence (kecerdasan majemuk). Secara umum delapan kecerdasan yang dimiliki manusia memiliki tingkat perkembangan yang berbeda. Namun, setiap orang (dalam hal ini siswa) dapat mengembangkan masing-masing kecerdasan hingga ke tingkat kompetensi yang memadai.

Salah satu kecerdasan yang dapat dikembangkan dan diuji tingkat kompetensinya adalah kecerdasan visual spasial. Kecerdasan visual spasial merupakan kemampuan mempersepsi dunia visual spasial secara akurat serta mentransformasikan persepsi visual spasial tersebut dalam berbagai bentuk (Yaumi, 2012:16). Lebih lanjut diungkapkan bahwa komponen inti dari kecerdasan visual spasial adalah kepekaan pada garis, warna, bentuk, ruang, keseimbangan, bayangan harmoni, pola, hubungan antar unsur, kemampuan membayangkan, mempresentasikan ide secara visual dan spasial, dan mengorientasikan secara tepat.

Sedangkan menurut Nurjannah \& Anjani (2016), visual spasial adalah 
kemampuan memahami, memproses, dan berpikir dalam bentuk visual dan mencitrakannya dalam bentuk dua atau tiga dimensi. Banyak cara yang dapat dilakukan untuk mengoptimalkan kecerdasan visual spasial pada siswa sejak dini, seperti: mengatur emosi, bermain bentuk, dan mengapresiasi gambar. Perkembangan kemampuan visual spasial diharapkan dapat menunjang kemampuan literasi matematika siswa, utamanya pada materi geometri.

Menurut Setiawan (dalam Jumarniati, dkk., 2016:68-69), literasi matematika diartikan sebagai kemampuan seseorang untuk merumuskan, menerapkan dan menafsirkan matematika dalam berbagai konteks, termasuk kemampuan melakukan penalaran secara matematis dan menggunakan konsep, prosedur, dan fakta untuk menggambarkan, menjelaskan atau memperkirakan fenomena/kejadian. Kemampuan literasi matematika pada siswa dapat dikembangkan secara bertahap sesuai dengan tingkat pemahaman siswa. Selain itu dalam pengembangan kemampuan literasi matematika juga perlu diperhatikan komponen pendukung yang menyertai proses pembelajarannya.

Menurut NCTM (National

Council of Teachers Mathematics), terdapat lima kompetensi dalam pembelajaran matematika yang merupakan komponen kemampuan literasi matematika, yaitu: pemecahan masalah (mathematical problem solving), komunikasi matematis (mathematical communication), penalaran matematis (mathematical reasoning), koneksi matematis (mathematical connection), dan representasi matematis (mathematical representation) (Fathani, 2016:140). Kelima komponen tersebut membutuhkan pendukung salah satunya dari kecerdasan visual spasial. Untuk itu diperlukan pengembangan kecerdasan visual spasial pada siswa sehingga menunjang kemampuan literasi matematikanya.

Salah satu penelitian tentang kemampuan visual spasial siswa menunjukkan bahwa ditemukan kemampuan secara mental dalam mengubah bentuk obyek geometris ke dalam bentuk yang berbeda dari siswa SMP berkemampuan tinggi, sedang dan rendah (Febriana, 2015:13). Namun subyek dengan kemampuan tinggi dan sedang memiliki kesulitan dalam merepresentasikan bayangan dimensi tiga ke dimensi dua pada bidang. Sedangkan subyek berkemampuan rendah memiliki kesulitan dalam membayangkan bentuk obyek dari perspektif yang berbeda. Hasil penelitian tersebut menunjukkan bahwa kemampuan visual spasial dapat dikembangkan melalui benda-benda geometri khususnya yang telah dikenal siswa.

Peningkatan kemampuan visual spasial dapat diterapkan dalam bentuk media pembelajaran. Media tersebut dapat diwujudkan dalam bentuk cetak maupun elektronik. Perkembangan media cetak yang beralih ke media elektronik serta minat siswa yang cukup besar terhadap media pembelajaran, diharapkan menjadi pendukung untuk diterapkannya cara-cara dalam mengoptimalkan kecerdasan visual spasial.

Media merupakan suatu hal yang diperlukan dalam setiap tahap proses perkembangan manusia. Media menempati posisi yang cukup penting sebagai salah satu komponen sistem pembelajaran, karena proses pembelajaran merupakan proses komunikasi dan berlangsung dalam suatu sistem.Menurut Cristicos (dalam 
Daryanto, 2015:4), media merupakan salah satu komponen komunikasi, yaitu sebagai pembawa pesan dari komunikator menuju komunikan. Pengertian media tersebut bersesuaian dengan pendapat Schram yang menyatakan bahwa media merupakan teknologi pembawa pesan yang dapat dimanfaatkan untuk keperluan pembelajaran (dalam Susilana dan Riyana, 2007:5).

Penggunaan media secara kreatif dapat memperlancar dan meningkatkan efesiensi pembelajaran sehingga tujuan pembelajaran dapat tercapai. Media pembelajaran juga sebagai sarana mewujudkan situasi pembelajaran yang efektif, merangsang siswa agar dapat menangkap tujuan dan bahan ajar lebih mudah dan lebih cepat, dan dapat meningkatkan kualitas proses pembelajaran. Pengembangan media pembelajaran juga dapat menggunakan teknologi seperti komputer.

Pemanfaatan komputer secara kreatif sebagaisalah satu produk teknologi dapat membuat media pembelajaran yang dihasilkan lebih variatif dan inovatif. Berbagai jenis aplikasi teknologi berbasis komputer dalam pembelajaranumumnya dikenal dengan istilah computer-assisted instruction atau pembelajarandengan bantuan komputer.Media pembelajaran berbasis komputer sangat diperlukan, sebab media komputer memiliki karakteristik yang mudah dipahami dan digunakan dalam pembelajaran. Menurut Joyce (dalam Musfiqon, 2011:193), teknologi tinggi yang berbasis komputer dan televisi memberi keluasan bagi siswa untuk mengadopsi pengetahuan dari media tersebut yang dapat mendukung pembelajaran di kelas.

Penelitian ini bertujuan untuk mengembangkan media elektronik berbasis kuis yang diharapkan dapat mengembangkan kemampuan visual spasial siswa sebagai pendukung kemampuan literasi matematika. Media yang dikembangkan berbasis bentukbentuk geometri dua dimensi (dibatasi pada persegi) dan tiga dimensi (dibatasi pada kubus). Proses penelitian merupakan tahap awal yang nantinya akan dikembangkan dengan bentukbentuk geometri yang lain. Hasil pengembangan media (pembelajaran) elektronik ini akan digunakan melatih kemampuan visual spasial siswa dengan harapan dapat menunjang kemampuan literasi matematikanya. Berkembangnya fungsi otak kanan diharapkan dapat mendukung pengembangan kecerdasan visual spasial siswa.

\section{METODE PENELITIAN}

Penelitian ini merupakan penelitian pengembangan yang dirancang dengan model ADDIE (Analysis, Design, Development, Implementation, Evaluation). Berdasarkan komponen yang dimiliki oleh model ADDIE, maka penelitian ini dilaksanakan berdasarkan alur penelitian berikut:

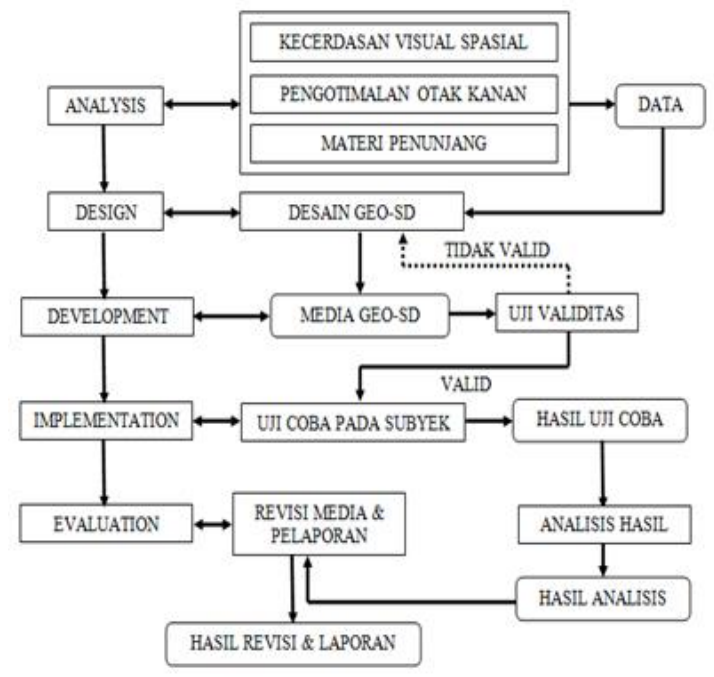

Gambar 1. Alur Penelitian

Penelitian diawali dengan menganalisa faktor-faktor yang mempengaruhi kecerdasan visual 
spasial, dilanjutkan dengan proses desain atau merancang media yang akan digunakan untuk mengembangkan kecerdasan visual spasial. Tahap berikutnya adalah merealisasikan rancangan media dalam bentuk media cetak (hard) yang memuat bentukbentuk geometri dimensi dua dan dimensi tiga, yang dihubungkan dengan pemahaman keruangan subyek penelitian. Media dalam bentuk cetak selanjutnya divalidasi untuk mengetahui kelayakan bentuk-bentuk geometri dimensi dua dan dimensi tiga yang digunakan. Selanjutnya media dalam bentuk cetak dikembangkan menjadi media elektronik berbasis kuis, yang memuat soal-soal dengan bentuk-bentuk geometris.

Media dalam bentuk elektronik selanjutnya diujicobakan pada subyek penelitian. Subyek ditentukan dengan cara purposive sampling dan snowball sampling. Subyek ditentukan dari siswa Sekolah Menengah Pertama. Hal ini dilakukan dengan dasar bahwa siswa SMP sudah memahami bentuk-bentuk geometris baik dimensi dua maupun dimensi tiga. Hasil ujicoba menjadi dasar revisi media dan pembuatan laporan berdasarkan analisis hasil penelitian.

Analisis data dilakukan untuk mengetahui efektivitas media yang telah dibuat dan dilakukan secara kualitatif dengan memperhatikan hasil ujicoba media pada subyek. Analisis data selain dilakukan pada hasil ujicoba, juga dilakukan pada hasil wawancara yang dilakukan untuk melengkapi data. Media dikatakan efektif dan dapat digunakan untuk melatih kecerdasan visual spasial jika terdapat peningkatan pada hasil ujicoba (baik dari segi perolehan nilai atau waktu yang dibutuhkan untuk penyelesaian) yang dilakukan pada subyek penelitian.

\section{HASIL PENELITIAN DAN PEMBAHASAN}

Media yang dikembangkan terinspirasi dari permainan rubik. Secara umum permainan rubik merupakan proses mencocokan posisi warna pada bagian-bagian persegi pada suatu kubus.

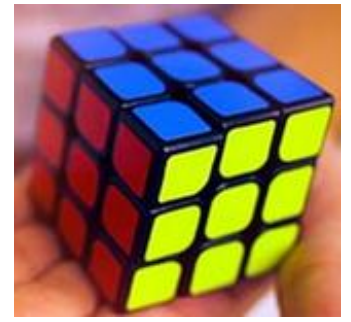

Gambar 2. Permainan Rubik (https://www.rubiks.com/)

Proses pencocokan warna tersebut menjadi dasar pembuatan media yang dihasilkan selanjutnya dinamakan GEOSD (geometri sketsa dimensi). Rancangan media GEO-SD dibuat dalam bentuk cetak (hard) yang memuat 14 soal bentuk geometris dimensi dua (2D) dan dimensi tiga (3D). 14 soal yang dimaksud terdiri dari
7 item soal yang melatih kemampuan dalam mengubah bentuk geometris 2D menjadi 3D dan 7 item soal yang melatih kemampuan dalam mengubah bentuk geometris 3D menjadi 2D, dalam bentuk pilihan ganda. Media tersebut kemudian diujicobakan kepada 9 responden yang merupakan siswa SMP kelas 7 sampai kelas 9 . 
ISSN 2089-8703 (Print) Vol. 7, No. 1 (2018)

ISSN 2442-5419 (Online)

Media GEO-SD elektronik dibuat dalam bentuk kuis berbasis komputer sesuai dengan bentuk cetak yang telah direvisi. Media GEO-SD elektronik dibuat dengan menggunakan software Wondershare Quiz Creator versi 4.1.0. Adapun tampilan awal dari GEO-SD dapat disajikan sebagai berikut.

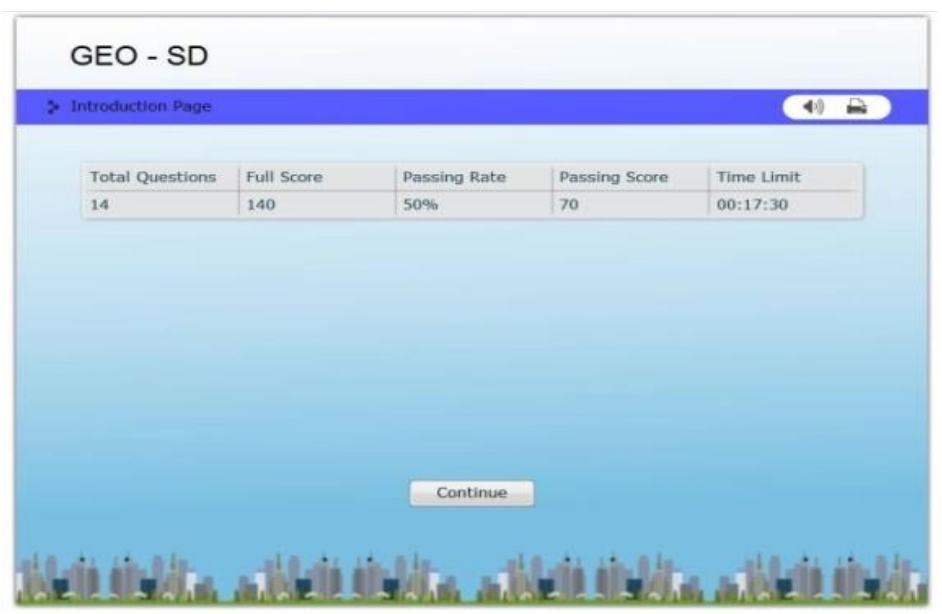

Gambar 3. Halaman Depan

Halaman depan memuat penjelasan bahwa terdapat 14 butir soal yang akan dikerjakan, dengan masing-masing soal bernilai 10 skor. Sehingga skor maksimal yang dapat diperoleh jika seluruh soal dapat diselesaikan dengan benar adalah 140. Waktu yang diberikan adalah 17 menit 30 detik. Waktu ini ditentukan berdasarkan ujicoba awal dari rancangan GEO-SD dalam bentuk cetak (hard). Untuk membuat tampilan kuis menjadi lebih menarik, didalamnya terdapat backsounds yang mengiringi jalannya kuis.

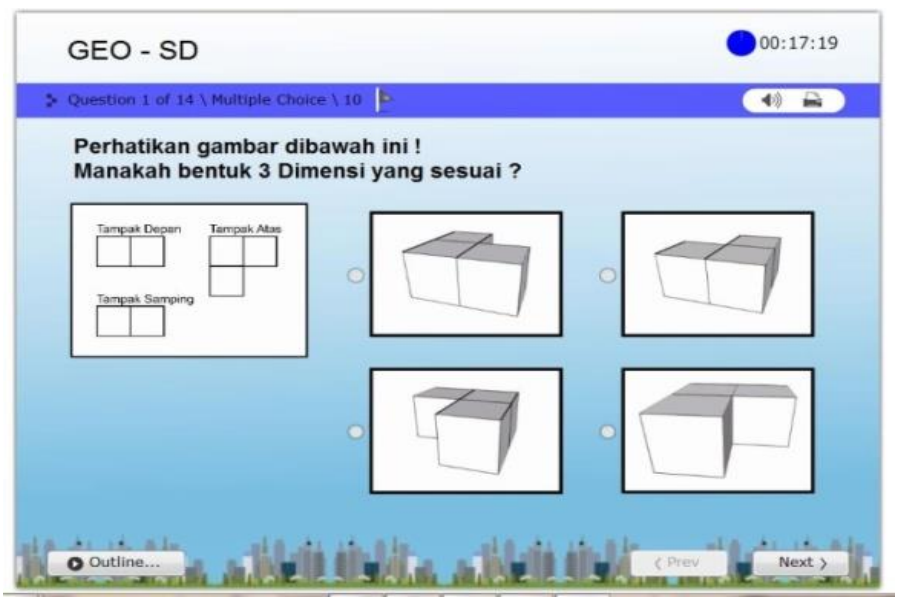

Gambar 4.Contoh soal 2D ke 3D pada GEO-SD

Halaman soal diberikan sebagai kuis bagi subyek untuk dikerjakan sesuai dengan waktu yang telah ditentukan. Terdapat 7 item soal pengubahan bentuk geometris $2 \mathrm{D}$ ke
3D. Subyek harus memilih salah satu pilihan yang telah disediakan. Setelah subyek menentukan pilihannya, subyek dapat menekan tombol next untuk melanjutkan ke soal berikutnya. Dan 
ISSN 2089-8703 (Print) Vol. 7, No. 1 (2018)

ISSN 2442-5419 (Online)

seterusnya hingga terselesaikan 7 soal pengubahan bentuk geometris $2 \mathrm{D} \mathrm{ke}$ 3D.

Penekanan tombol next setelah penyelesaian soal ke-7 akan memunculkan soal ke-8 yang merupakan soal pengubahan bentuk geometris 3D ke 2D, seperti pada gambar berikut.

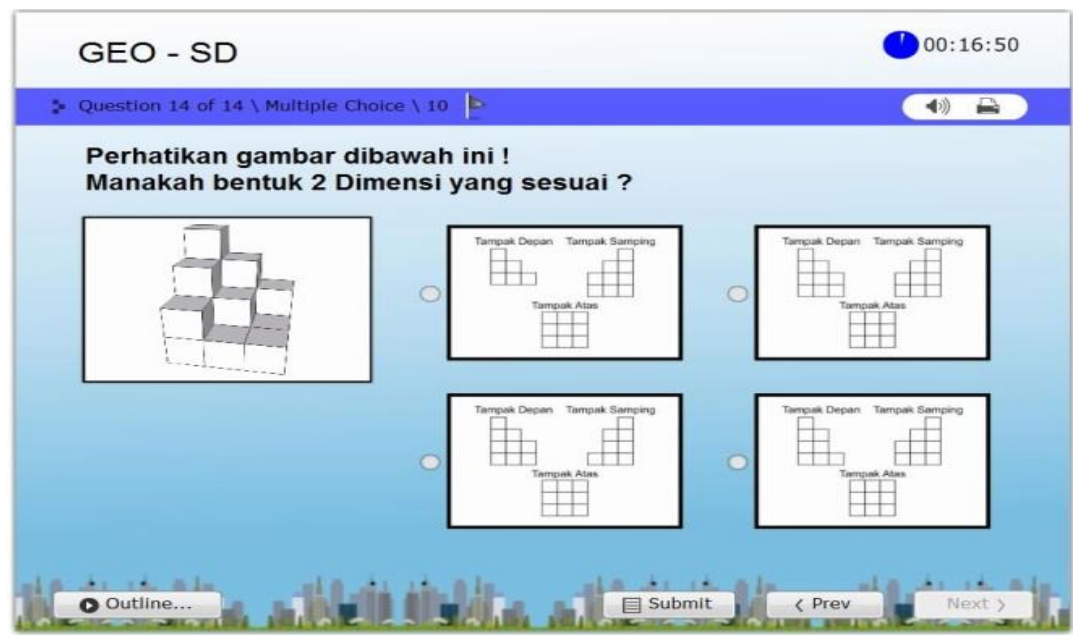

Gambar 5. Contoh soal 3D ke 2D pada GEO-SD

Sesuai dengan soal sebelumnya, subyek juga harus menentukan satu jawaban yang sesuai dari pengubahan bentuk geometris 3D ke 2D. Soal yang diberikan juga sebanyak 7 item.

Setelah subyek menyelesaikan 14 soal yang telah diberikan, subyek dapat menekan tombol prev untuk meyakinkan pilihan jawaban, atau menekan tombol submit untuk mengetahui skor akhir dan memunculkan tampilan berikut:

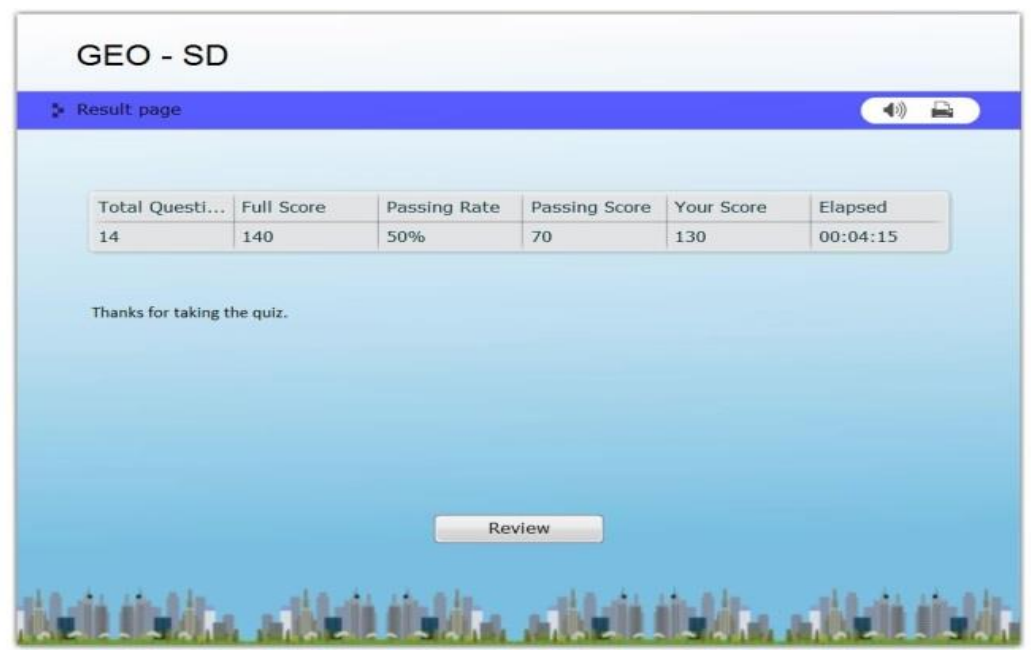

Gambar 6. Contoh Hasil Ujicoba

Halaman ini menunjukkan hasil kuis yang diperoleh subyek.Sebagai contoh subyek mendapat skor 130 dan waktu yang digunakan adalah 4 menit
15 detik, artinya subyek mengalami kesalahan pada satu soal dan membutuhkan waktu 4 menit 15 detik 
ISSN 2089-8703 (Print) Vol. 7, No. 1 (2018)

ISSN 2442-5419 (Online)

untuk menyelesaikan kuis secara keseluruhan.

Untuk mengetahui detail hasil dan kesalahan subyek, dapat dilakukan

dengan menekan tombol review, kemudian pilih outline sehingga muncul tampilan berikut:

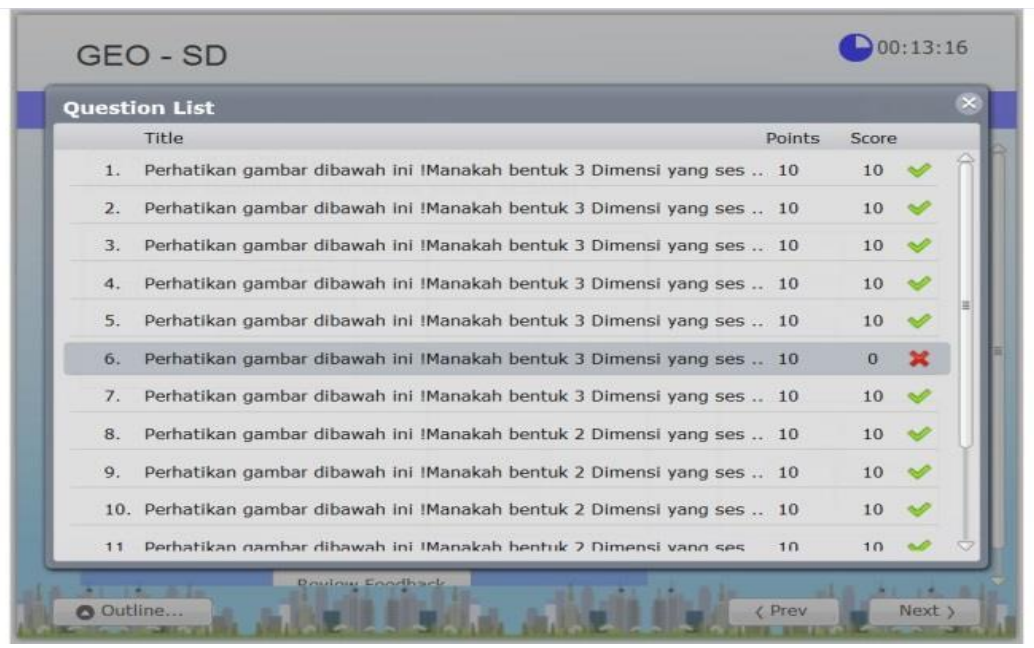

Gambar 7. Tampilan Outline

Halaman ini menyajikan hasil yang menunjukkan detail kesalahan jawaban subyek.

Analisis data dilakukan terhadap hasil ujicoba yang diberikan kepada subyek berdasarkan indikator ketepatan penentuan pemilihan hasil yang bersesuaian dan waktu yang diperlukan subyek dalam mencapai ketepatan tersebut. Media GEO-SD dikatakan efektif dalam meningkatkan kemampuan visual spasial subyek jika terjadi peningkatan skor pada ketepatan jawaban subyek dan berkurangnya waktu yang dibutuhkan dalam penentuan jawaban.

Hasil ujicoba yang dimaksud adalah hasil ujicoba dalam bentuk cetak (hard) dan media GEO-SD. Hasil ujicoba merupakan skor yang diperoleh serta waktu yang dibutuhkan subyek dalam menyelesaikan soal-soal kuis. Berikut hasil dari ujicoba pada masingmasing subyek:

Tabel 1. Hasil Ujicoba Berdasarkan Ketepatan Jawaban Subyek

\begin{tabular}{cccc}
\hline \multirow{2}{*}{ No } & \multirow{2}{*}{ Responden } & \multicolumn{2}{c}{ Skor } \\
& & Hardcopy & Softcopy \\
\hline 1 & $\mathrm{~S}_{1}$ & 100 & 130 \\
2 & $\mathrm{~S}_{2}$ & 80 & 110 \\
3 & $\mathrm{~S}_{3}$ & 100 & 140 \\
4 & $\mathrm{~S}_{4}$ & 100 & 120 \\
5 & $\mathrm{~S}_{5}$ & 70 & 90 \\
6 & $\mathrm{~S}_{6}$ & 100 & 40 \\
7 & $\mathrm{~S}_{7}$ & 80 & 40 \\
8 & $\mathrm{~S}_{8}$ & 140 & 130 \\
9 & $\mathrm{~S}_{9}$ & 70 & 70 \\
\hline
\end{tabular}

16| Aksioma

Jurnal Pendidikan Matematika FKIP Univ. Muhammadiyah Metro 
Hasil ujicoba berdasarkan jawaban benar yang diperoleh subyek menunjukkan bahwa terdapat 5 subyek yang mengalami peningkatan skor. 1 subyek tidak mengalami peningkatan skor, dan 3 subyek mengalami penurunan skor. Hasil perolehan skor menunjukkan bahwa terdapat peningkatan kemampuan subyek dalam menyelesaikan kuis dengan menggunakan media GEO-SD.

Tabel 2. Hasil Ujicoba Berdasarkan Waktu Yang Dibutuhkan

\begin{tabular}{cccc}
\hline \multirow{2}{*}{ No } & \multirow{2}{*}{ Responden } & \multicolumn{2}{c}{ Waktu (detik) } \\
& & Hardcopy & Softcopy \\
\hline 1 & $\mathrm{~S}_{1}$ & 686 & 458 \\
2 & $\mathrm{~S}_{2}$ & 801 & 545 \\
3 & $\mathrm{~S}_{3}$ & 899 & 596 \\
4 & $\mathrm{~S}_{4}$ & 497 & 375 \\
5 & $\mathrm{~S}_{5}$ & 1133 & 1050 \\
6 & $\mathrm{~S}_{6}$ & 515 & 487 \\
7 & $\mathrm{~S}_{7}$ & 931 & 1025 \\
8 & $\mathrm{~S}_{8}$ & 1053 & 808 \\
9 & $\mathrm{~S}_{9}$ & 1459 & 587 \\
\hline
\end{tabular}

Berdasarkan waktu yang dibutuhkan dapat diperoleh bahwa ratarata waktu yang digunakan subyek dalam menyelesaikan kuis mengalami penurunan. Artinya subyek mampu menyelesaikan soal-soal yang diberikan dalam media GEO-SD lebih cepat. Hal ini menunjukkan bahwa media GEO-SD mampu mempersingkat waktu yang dibutuhkan subyek.

Berdasarkan hasil ujicoba dan analisis data dapat dikatakan bahwa media GEO-SD efektif digunakan meningkatkan kemampuan visual spasial subyek. Hasil penelitian ini masih memerlukan pengembangan ujicoba lebih lanjut. Hasil wawancara terhadap subyek juga menunjukkan bahwa masih terdapat banyak faktor yang mempengaruhi hasil penggunaan media GEO-SD, diantaranya:

1. Subyek kurang fokus atau konsentrasi selama mengerjakan kuis
2. Subyek masih terlalu fokus dengan tugas sekolah

3. Subyek merasa tidak nyaman atau tidak yakin saat mengerjakan kuis

4. Pengaruh lingkungan dalam proses penyelesaian kuis (adanya gangguan suara-suara disekitar lokasi ujicoba)

Namun demikian penggunaan media GEO-SD mengindikasikan bahwa subyek sudah mulai mengalami perkembangan dalam membayangkan atau melihat suatu obyek atau dalam hal ini bentuk-bentuk geometris pada dimensi dua (2D) serta dimensi tiga (3D).

\section{KESIMPULAN DAN SARAN}

Pengembangan media elektronik berbasis kuis ini menghasilkan suatu media yang diberi nama Geo-SD (Geometri Sketsa Dimensi). Konsep pengembangan dilakukan berdasarkan bentuk-bentuk geometris pada dimensi dua (2D) dan dimensi tiga (3D). Secara 
umum pengembangan konsep visual spasial yang diharapkan dari siswa adalah pemahaman tentang penampakan bentuk-bentuk dari dimensi dua ke dimensi tiga atau sebaliknya.

Hasil ujicoba terbatas yang dilakukan pada subyek menunjukkan bahwa Geo-SD efektif dalam mengembangkan kemampuan visual spasial subyek. Namun hal ini masih memerlukan ujicoba lebih pada subyek dengan jumlah yang lebih besar untuk dapat menentukan keakuratannya.

\section{DAFTAR PUSTAKA}

Daryanto. 2015. Media Pembelajaran. Bandung: PT. Sarana Tutorial Nurani Sejahtera.

Fathani, A. H. 2016. Pengembangan Literasi Matematika Sekolah dalam Perspektif Multiple Intelligences. EduSains, Vol. 4, No. 2, Hal. 136 - 150.

Febriana, E. 2015. Profil Kemampuan Spasial Siswa Menengah Pertama (SMP) dalam Menyelesaikan Masalah Geometri Dimensi Tiga Ditinjua dari Kemampuan Matematika. Jurnal Elemen. Vol. 1, No. 1, Hal. $13-23$.

Jumarniati, P. R. F., \& Riady, A. 2016. Kemampuan Literasi Matematika dalam Menyelesaikan Masalah Turunan Fungsi Trigonometri. Jurnal Pedagogy. Vol. 1, No. 2, Hal. $66-75$.

Musfiqon, H. 2012. Pengembangan Media dan Sumber Pembelajaran. Jakarta: PT. Prestasi Pustakaraya.

Nurjannah, S., \& Anjani, D. A. 2016. Permainan Puzzle Mempengaruhi Perkembangan Kecerdasan Visual-Spatial Anak Usia 4-5 Tahun di TK Al-Fath
Desa Keboan Anom Gedangan Sidoarjo. Jurnal Ilmiah Kesehatan. Vol. 7, No. 2, Hal. 186-192.

Susilana, R., \& Riyana, C. 2007. Media Pembelajaran. Bandung: CV. Wacana Prima.

Yaumi, M. 2012. Pembelajaran Berbasis Multiple Intelligences. Jakarta: Dian Rakyat. 